\title{
The convict cichlid Amatitlania nigrofasciata (Cichlidae): first record of this non-native species in Western Australian waterbodies
}

\author{
Rodney Duffy, Michael Snow and Chris Bird \\ Western Australian Fisheries and Marine Research Laboratories, 39 Northside Drive, Hillarys, \\ Western Australia 6025, Australia. Email: Rodney.Duffy@fish.wa.gov.au
}

KEYWORDS: feral fish, pest, introduced, South West drainage division, Swan Coastal Plain

\section{INTRODUCTION}

The southwest of Western Australia is recognised as a global biodiversity hotspot (Myers et al. 2000), and although it is relatively depauperate in freshwater fish biodiversity, these species have high rates of endemicity (Morgan, Gill and Potter 1998). The South West drainage division includes the Swan Coastal Plain, a long (approximately $600 \mathrm{~km}$ ) and narrow $(30 \mathrm{~km}$ at its widest point) plain extending from Geraldton to Cape Leeuwin that is bordered by the Indian Ocean and the Darling Escarpment (Cummings and Hardy 2000; Thackway and Cresswell 1995).

Establishment of non-native species outside their natural range is a major threat to endemic species (Canonico et al. 2005; Courtenay and Stauffer 1990; Dudgeon et al. 2006) and has been identified as a major cause of extinctions (Reid et al. 2005). The incidence of introductions of non-native fish to freshwater environments of Australia has increased (Arthington et al. 1999; Lintermans 2004). Freshwater systems are often subject to both acute and chronic anthropogenic interactions and as a result suffer a high risk of introductions (Costanza et al. 1998; Gherardi 2007; Rahel 2007). The Swan Coastal Plain has the highest population density in the state of Western Australia (ABS 2011); therefore, freshwater systems in this area are particularly vulnerable to non-native fish introduction.

The convict cichlid, Amatitlania nigrofasciata Gunther, 1867 has a history of taxonomic confusion (Schmitter-Soto 2007a; Schmitter-Soto 2007b; Smith et al. 2008), most recently being moved from the genus Archocentrus to Amatitlania in 2007 (Schmitter-Soto 2007a; Schmitter-Soto 2007b). It is naturally found in Central American rivers and lakes on the Pacific slope from Rio Sucio, El Salvador to Rio Suchiate, Guatemala; and the Atlantic slope from Rio Patuca, Honduras to Rio Jutiapa, Guatemala (Schmitter-Soto 2007a). It has established wild populations in the USA (Hawaii), Mexico, Israel, Japan and Australia (Ishikawa and Tachihara 2010; Welcomme 1988).

The species is a member of the Cichlidae, a family of fish known for prolonged biparental care of offspring (Bernstein 1980; Keenleyside 1991). Due to confusion over taxonomy, the various studies of convict cichlids may not all represent the same species. However, all species are closely related, and therefore the results of behavioural studies are broadly applicable across the group. The convict cichlid group has been extensively studied in the laboratory (Wisenden 1995) but despite significant research, few studies have investigated the life history of Amatitlania nigrofasciata in natural environments. Adults were shown to reach $100 \mathrm{~mm}$ standard length (SL) (Kullander 2003) and mature females were found at $32 \mathrm{~mm} \mathrm{SL}$ in introduced populations in Japan (Ishikawa and Tachihara 2010). This size is similar to that reported for the closely related Amatitlania siquia ${ }^{1}$, whose males mature at sizes as small as $51 \mathrm{~mm}$ SL, and is a species which has received more intensive study (Wisenden 1995). Parental pairs are monogamous, and in the introduced population in Japan, bred throughout the year despite water temperatures of less than $20^{\circ} \mathrm{C}$ (Ishikawa and Tachihara 2010). Amatitlania siquia excavates small caves under hard substrate and lays its eggs on the roof of these caves (Wisenden 1995). Both sexes care for the young (Noonan 1983) with adult fish caring for the brood by shepherding juveniles when outside the cave (Wisenden et al. 1995) and returning them to the cave at night for shelter, where adults stand guard and defend against potential predators (Gagliardi-Seeley and Itzkowitz 2009; Wisenden 1995). The non-native population in Japan exhibits rapid growth in the first

\footnotetext{
1 Wisenden 1995 reports on Amatitlania nigrofasciata, however based on the distribution described by Schmitter-Soto 2007, this species is $A$. siquia (refer to Ishikawa and Tachihara 2010)
} 
year, early maturation, a long spawning period, multiple spawnings and a short life span (Ishikawa and Tachihara 2010). Although tropical, the population in Japan has survived water temperatures as low as $17.1^{\circ} \mathrm{C}$ (Ishikawa and Tachihara 2010).

Within Australia, two populations have been reported. One population has existed in the artificially warmed waters of the Hazelwood Power Station cooling ponds in Victoria since 1978 (Allen 1989). The second population was purported to occur in Queensland by Koehn and MacKenzie (2004), however examination of the literature referenced to substantiate the presence of this population; Arthington and McKenzie (1997); Arthington and Bluhdorn (1995); and DPIQ (2001), reveals no reference to this species.

This report documents the first finding of Amatitlania nigrofasciata in a waterbody within Western Australia.

\section{MATERIALS AND METHODS}

A survey of waterbodies in the region bounded by the Perth suburbs of Parkwood, Huntingdale, Southern River and Canning Vale (Figure 1) was undertaken as part of the Western Australian Department of Fisheries survey program for introduced fish species. Sampling occurred during two intensive field surveys conducted in December 2011 and February 2012, although each lake was only sampled on one occasion. A total of 41 lakes was surveyed using paired single - winged fykes (5m wing, 6mm stretched mesh). The pair of nets was set perpendicular to the shore, with the wing of the second fyke attached to the codend of the first. Between one and four of these nets were set in each lake, depending on the size of the waterbody.

Specimens of $A$. nigrofasciata were euthanased in an ice slurry. Hybridisation amongst cichlids in the aquarium trade is common, therefore to identify the species, genetic techniques were used. A small piece (approx. $5 \mathrm{~mm}^{3}$ ) of muscle tissue was excised from each fish specimen. DNA was extracted from each sample using the FavorPrep ${ }^{\mathbf{T M}}$ Tissue Genomic DNA Extraction Mini Kit according to the manufacturer's instructions (Favorgen). DNA was eluted in a final volume of $100 \mu 1$ of elution buffer. PCR was conducted using $1 \mu 1$ template DNA in a final reaction volume of $25 \mu \mathrm{l}$ which contained $2.5 \mu 1$ 10x DNA polymerase PCR buffer (Fisher Biotech), 1U Taq DNA Polymerase (Fisher Biotech), $2.5 \mu 125 \mathrm{mM}$ $\mathrm{MgCl}_{2}, 1.25 \mu \mathrm{dNTPs}(1 \mathrm{mM}$ each) and $1 \mu \mathrm{l}$ each primer $(2.5 \mu \mathrm{M}$ stock). Primers used for amplification were those previously reported for use in barcoding of fish as follows: FOR 5' TCA ACC AAC CAC AAA GAC ATT GGC AC 3' and REV 5' TAG ACT TCT GGG

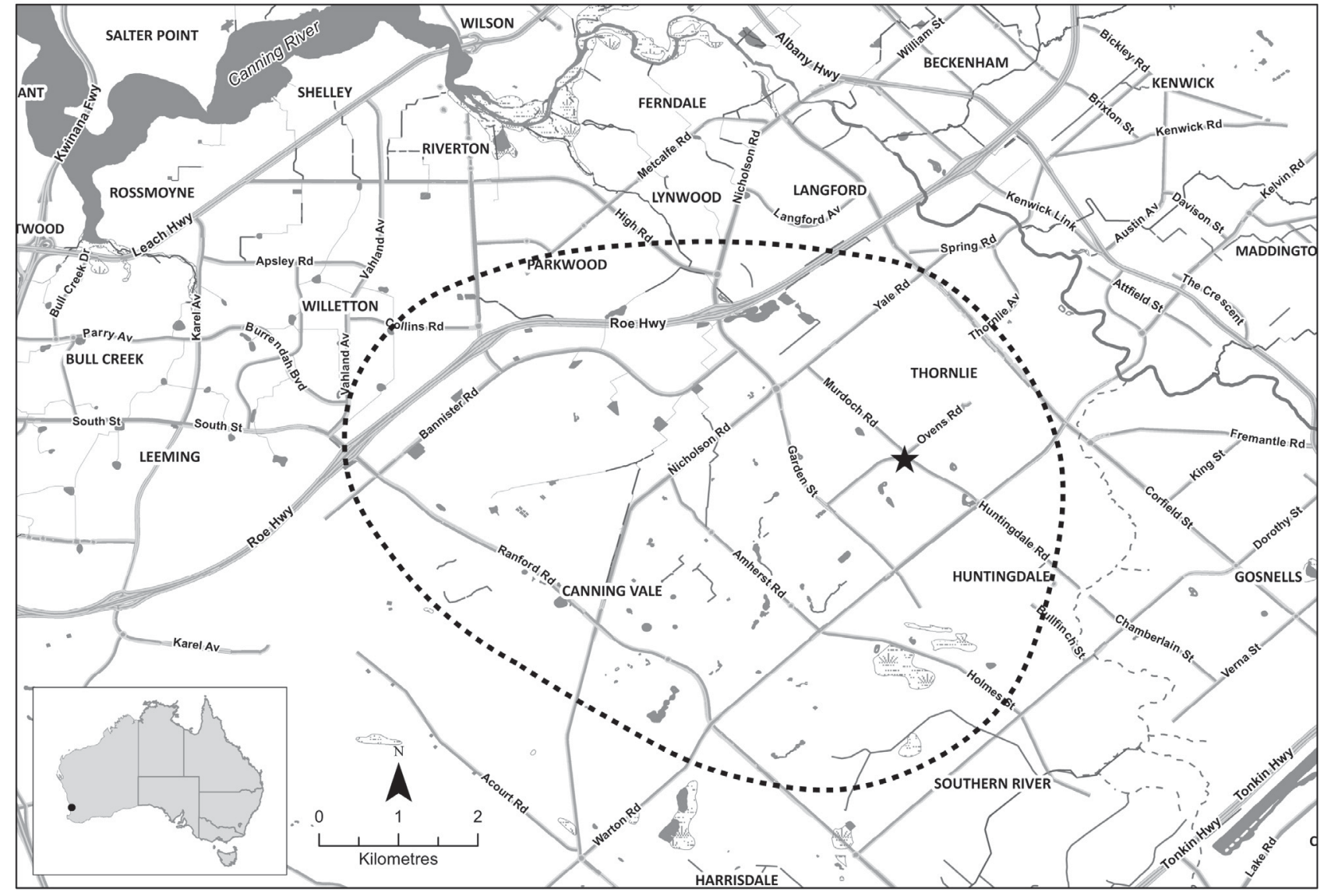

FIGURE 1 Location of sampling area. The location of the lake containing Amatitlania nigrofasciata is marked with a star. 


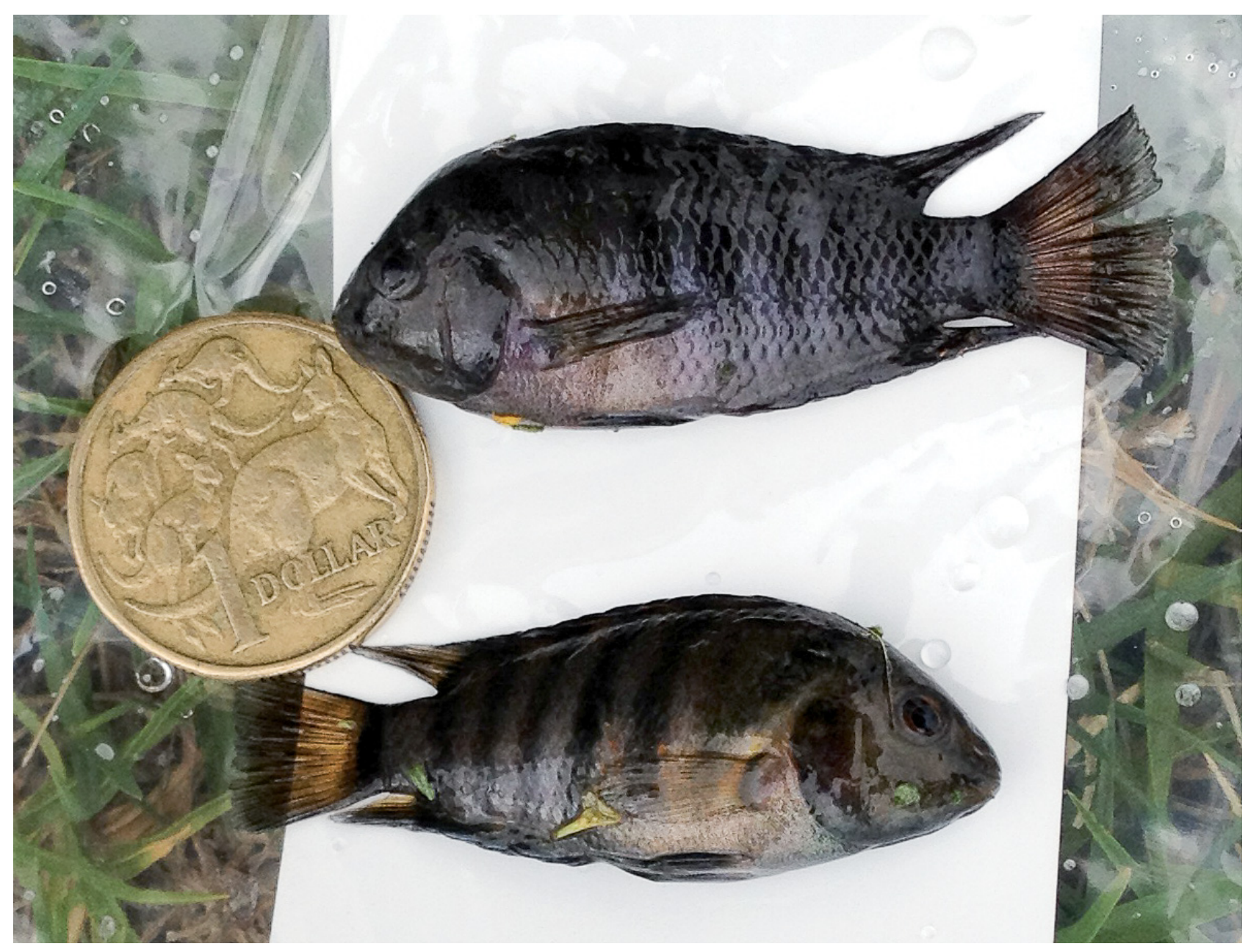

FIGURE 2 Convict cichlids, Amatitlania nigrofasciata captured from a waterbody in the greater Perth region.

TGG CCA AAG AAT CA 3' (Ward et al, 2005). PCR was conducted on an Applied Biosystems Thermal Cycler 2720 programmed to conduct the following cycling regime: $94^{\circ} 1 \mathrm{~min}(\mathrm{x} 1) ; 94^{\circ} \mathrm{C} 40 \mathrm{~s}, 45^{\circ} \mathrm{C} 40 \mathrm{~s}$, $72^{\circ} \mathrm{C} 1 \mathrm{~min}(\mathrm{x} 5) ; 94^{\circ} \mathrm{C} 40 \mathrm{~s}, 51^{\circ} \mathrm{C} 40 \mathrm{~s}, 72^{\circ} \mathrm{C} 1 \min (\mathrm{x} 35)$. Products were visualised under UV light following electrophoresis and staining with ethidium bromide.

PCR products were commercially sequenced (AGRF Perth) in forward and reverse orientations using the same primers used for original PCR. Forward and reverse sequences were aligned using the program Sequencher 4.8 (Gene Codes) to generate a consensus CO1 sequence for each specimen. The final consensus sequences representing $655 \mathrm{bp}$ of the $\mathrm{CO} 1$ gene were used to interrogate the Barcode of Life database (http:// www.boldsystems.org/).

\section{RESULTS AND DISCUSSION}

\section{IDENTIFICATION}

Consensus sequences obtained from each specimen were identical. Interrogation of the Barcode of Life Database identified the species as Amatitlania nigrofasciata with $100 \%$ probability of placement to the species level. Hits were generated with 10 specimens at $>99.08$ specimen similarity and provide an unequivocal DNA based identification. Following identification, specimens were preserved in $100 \%$ ethanol and lodged with the Western Australian Museum (WAM P.33814001).

\section{INTRODUCED SPECIES BIODIVERSITY}

Two individuals of convict cichlid, Amatitlania nigrofasciata (Figure 2), were captured in December, 2011, in a single lake within Forest Crescent Reserve (Latitude -32.071, Longitude 115.952). Lengths of the specimens were $45 \mathrm{~mm}$ and $43 \mathrm{~mm}$ SL. Determination of sex of specimens was not possible due to the small size and deterioration after preservation.

At the time of sampling, no native fish species were present in the waterbody, but 700 tadpoles were captured and returned to the lake. The only other fish species captured were 100 non-native mosquito fish, Gambusia holbrooki. Follow up sampling was undertaken in June 2012, however, the catch consisted of $180 \mathrm{G}$. holbrooki, 7 yabbies, Cherax destructor albidus, and no individuals 
TABLE 1 Introduced species present in the South West drainage division, and Swan Coastal Plain of Western Australia (DoF 2012).

\begin{tabular}{|c|c|c|c|c|}
\hline Family & Species & Common Name & South West drainage division & Swan Coastal Plain \\
\hline Cichlidae & Geophagus braziliensis & Pearl Cichlid & $\checkmark$ & $\checkmark$ \\
\hline \multirow[t]{3}{*}{ Cyprinidae } & Carassius auratus & Goldfish & $\checkmark$ & $\checkmark$ \\
\hline & Cyprinus carpio & Common Carp & $\checkmark$ & $\checkmark$ \\
\hline & Puntius conchonius & Rosy Barb & $\checkmark$ & $\checkmark$ \\
\hline Percichthyidae & Macquaria ambigua & Golden Perch & $\checkmark$ & $\checkmark$ \\
\hline Percidae & Perca fluviatilis & Redfin Perch & $\checkmark$ & $\checkmark$ \\
\hline Plotosidae & Tandanus tandanus & Eel tailed catfish & $\checkmark$ & $\checkmark$ \\
\hline \multirow[t]{3}{*}{ Poeciliidae } & Gambusia holbrooki & Mosquitofish & $\checkmark$ & $\checkmark$ \\
\hline & Phalloceros caudimaculatus & One-spot livebearer & $\checkmark$ & $\checkmark$ \\
\hline & Xiphophorus helleri & Swordtail & $\checkmark$ & \\
\hline \multirow[t]{2}{*}{ Salmonidae } & Onocorhynchus mykiss* & Rainbow trout & $\checkmark$ & $\checkmark$ \\
\hline & Salmo trutta* & Brown trout & $\checkmark$ & \\
\hline \multirow[t]{2}{*}{ Terapontidae } & Bidyanus bidyanus & Silver Perch & $\checkmark$ & $\checkmark$ \\
\hline & Leiopotherapon unicolor & Spangled Perch & $\checkmark$ & $\checkmark$ \\
\hline
\end{tabular}

* Species stocked by the Western Australian Department of Fisheries for recreational fishing.

of A. nigrofasciata. Future sampling will continue to assess and monitor the status of $A$. nigrofasciata in this waterbody.

The capture described herein, represents the first and only record of this species being captured from the wild in Western Australia and only the second record of this species in the wild in Australia. This record brings the total number of introduced fish species recorded in the Swan Coastal Plain to 13 and in the South West drainage division to 15 (DoF 2012), outnumbering the 11 native fish species known to inhabit the same regions (Somner et al. 2008; Hourston et al. unpublished data) (Table 1).

Follow up sampling did not capture additional specimens, therefore it is possible that this species has not established a self-maintaining population despite an apparent serious risk. Further sampling will be undertaken in summer 2012-13 to confirm the eradication. The absence of individuals in follow up sampling is possibly a result of this species being unable to survive winter water temperatures in this region. Water temperature was not recorded during either sampling event, although in Perth they can fall well below $15^{\circ} \mathrm{C}$.

\section{POTENTIAL IMPACTS}

Identification of the specific diet of $A$. nigrofasciata is difficult due to confusion resulting from recent taxonomic changes and the associated distribution of each species. However, it is reasonable to assume that diet of cichlids in the genus Amatitlania are reasonably similar. Based on this assumption, the diet of $A$. nigrofasciata in the South West drainage division is likely to consist of a large amount of plant material and organic matter, as well as amphipods, insects and fishes (Burcham 1988; BussingBurhaus 1993; Hill and Cichra 2005). Amatitlania nigrofasciata have been found to dominate abundance and biomass in foreign waterbodies (Trujillo-Jimenez et al. 2010). They have greater mass than most of the native freshwater fish of the same length in the South West drainage division and are also an aggressive species with brood care (Keenleyside 1991). Should A. nigrofasciata 
establish a self-maintaining population, it is likely to have a severe negative ecological impact through the modification of biodiversity.

Eradication of species after establishment is difficult and costly. Early detection is often considered the most important step toward preventing the establishment of introduced species. To prevent further introductions, hobbyists and the community need to be aware of the potential impacts of the release of ornamental fish into waterbodies and to avoid this practice. The detection of the convict cichlid demonstrates the importance of an intensive sampling program targeting pest fish in high risk waterbodies in an effort to conserve endemic and threatened fish fauna.

\section{ACKNOWLEDGEMENTS}

Thanks to Seema Fotedar for genetic analysis, Dr Craig Lawrence, Bruce Mackay, Dr Mat Hourston and Dean Meredith for reviewing the document, and two referees for their useful comments.

\section{REFERENCES}

ABS (2011). Regional Population Growth, Australia, cat. no. 3218.0. http://www.abs.gov.au/ausstats/abs@.nsf/Products/3 218.0 2011 Main+Features $\sim$ Western+Australia?OpenDocu ment. Accessed 27 August 2012.

Allen, G.R. (1989). Freshwater Fishes of Australia. TFH Publications: New Jersey.

Arthington, A. and McKenzie, F. (1997). Review of impacts of displaced/introduced fauna associated with inland waters. Australia: State of the Environment Technical Paper Series. Department of the Environment: Canberra.

Arthington, A.H., Griffith University and Australian Quarantine and Inspection Service. (1999). Baseline environmental data relevant to an evaluation of quarantine risk potentially associated with the importation to Australia of ornamental finfish, 1999 : report to the Australian Quarantine and Inspection Service (AQIS). Griffith University: Brisbane.

Bernstein, J.W. (1980). Parental care behavior in the cichlid fish Cichlasoma nigrofasciatum. Copeia 4: 682-686.

Burcham, J. (1988). Fish communities and environmental characteristics of two lowland streams in Costa Rica. Revista de Biologia Tropical 36: 273-285.

Bussing-Burhaus, W. A. (1993). Fish communities and environmental chracteristics of a tropical rain forest river in Costa Rica. Revista de Biologia Tropical 41: 791-809.

Canonico, G.C., Arthington, A., McCrary, J.K. and Thieme, M.L. (2005). The effects of introduced tilapias on native biodiversity. Aquatic Conservation: Marine and Freshwater Ecosystems 15: 463-483.

Costanza, R., d'Arge, R., de G.R., Farber, S., Grasso, M., Hannon, B., Limburg, K., Naeem, S., O'Neill, R.V., Paruelo, J., Raskin, R.G., Sutton, P. and van den Belt, M. (1998). The value of the world's ecosystem services and natural capital. Ecological Economics 25: 3-15.

Courtenay, W.R. and Stauffer, J.R. (1990). The introduced fish problem and the aquarium fish industry. World Aquaculture Society Journal 21: 145-159.

Cummings, B. and Hardy, A. (2000). Revision of the Interim
Biogeographic Regionalisation for Australia (IBRA) and Development of Version 5.1 [internet site]: summary report. Environment Australia, Canberra

Dudgeon, D., Arthington, A., Gessner, M.O., Kawabata, Z.L., Knowler, D.J., Leveque, C., Naiman, R.J., PrieurRichards, A.H., Stiassny, M.L.J. and Sullivan, C.A. (2006). Freshwater biodiversity: importance, threats, status and conservation challenges. Biological Review 81: 163-182.

Gagliardi-Seeley, J. and Itzkowitz, M. (2009). Does being paired give male and female convict cichlids (Amatitlania nigrofasciata) an advantage when competing against samesex individuals? Acta Ethologica 2009: 115-120.

Gherardi, F. (2007) Biological invasions in inland waters: an overview. In: Eds Gherardi, F. (ed.) Biological invaders in inland waters: Profiles, distribution, and threats: 3-25. Springer: Netherlands.

Hill, J.E. and Cichra, C.E. (2005). Eradication of a reproducing population of convict cichlids, Cichlasoma nigrofasciatum (Cichlidae), in north-central Florida. Florida Scientist 68: 65-74.

Ishikawa, T. and Tachihara, K. (2010). Life history of the nonnative convict cichlid Amatitilania nirgofasciata in the Haebaru Reservoir on Okinawa-jima Island, Japan. Environmental Biology of Fishes 88: 283-292.

Keenleyside, M.H.A. (1991) Parental care. In: Cichlid fishes: Behaviour, ecology and evolution: 191-208. Chapman and Hall: London.

Koehn, J.D. and MacKenzie, R.F. (2004). Priority management actions for alien freshwater fish species in Australia. New Zealand Journal of Marine and Freshwater Research 38: 457-472.

Kullander, S.O. (2003) Family Cichlidae (Cichlids). In: Reis, R.E., Kullander, S.O., and Ferraris, C.J., Jr., Checklist of the Freshwater Fishes of South and Central America: 605-654. Edipucrs: Porto Alegre.

Lintermans, M. (2004). Human assisted dispersal of alien freshwater fish in Australia. New Zealand Journal of Marine and Freshwater Research 38: 481-501.

Morgan, D.L., Gill, H.S. and Potter, I.C. (1998). Distribution, identification and biology of freshwater fishes in southwestern Australia. Records of the Western Australian Museum Supplement 56.

Myers, N., Mittermeier, R.A., Mittermeier, C.G., da Fonseca, G.A.B. and Kent, J. (2000). Biodiversity hotspots for conservation priorities. Nature 403: 853-858.

Noonan, K.C. (1983). Female mate choice in the cichlid fish Cichlasoma nigrofasciatum. Animal Behaviour 31: 10051010.

Rahel, F.J. (2007). Biogeographic barriers, connectivity and homogenization of freshwater faunas: it's a small world after all. Freshwater Biology 52: 696-710.

Reid, W.V., Mooney, H.A., Cropper, A., Capistrano, D., Carpenter, S.R., Chopra, K., Dasgupta, P., Dietz, T., Duraiappah, A.K., Hassan, R., Kasperson, R., Leemans, R., May, R.M., McMichael, T.A.J., Pingali, P., Samper, C., Scholes, R., Watson, R.T., Zakri, A.H., Shidong, A., Ash, N.J., Bennett, E., Kumar, P., Lee, M.J., RaudseppHearne, C., Simons, H., Thonell, J. and Zurek, M.B. (2005). Ecosystems and human well-being. Synthesis. A report to the Millenium Ecosystems Assessment. Island Press: Washington DC.

Schmitter-Soto, J.J. (2007a). A systematic revision of the genus Archocentrus (Perciformes: Cichlidae), with the description 
of two new genera and six new species. Zootaxa 1603: 1-78.

Schmitter-Soto, J.J. (2007b). Phylogeny of species formely assigned to the genus Archocentrus (Perciformes: Cichlidae). Zootaxa 1618: 1-50.

Smith, W.L., Chakrabarty, P. and Sparks, J.S. (2008). Phylogeny, taxonomy, and evolution of Neotropical cichlids (Teleostei: Cichlidae: Cichlinae). Cladistics 24: 625-641.

Somner, B., Horwitz, P. and Hewitt, P. (2008). Assessment of wetland invertebrate and fish biodiversity for the Gnangara Sustainability Strategy (GSS). Western Australia Department of Environment and Conservation: Perth.

Thackway, R. and Cresswell, I.D. (1995). An interim biogeographic regionalisation for Australia: a framework for setting priorities in the National Reserves System Cooperative Program. Australian Nature Conservation Agency: Canberra.

Trujillo-Jimenez, P., López-Lopez, E., Díaz-Pardo, E. and Camargo, J.A. (2010). Patterns in the distirubtion of fish assemblages in Río Amacuzac, Mexico: influence of abiotic factors and biotic factors. Reviews in Fish Biology and Fisheries 20: 457-469.

Ward, R.D., Zemlak, T.S., Innes, B.H., Last, P.R. and Hebert, D.N. (2005). DNA barcoding Australia's fish species. Philisophical Transactions of the Royal Society of Biological Sciences 360 (1462): 1847-1857.

Welcommem R.L. (1988). International introductions of inland aquatic species. FAO fisheries technical paper 294. Food and Agriculture Organisation of the United Nations: Rome.

Wisenden, B.D. (1995). Reproductive behaviour of freeranging convict cichlids, Cishlasoma nigrofasciatum. Environmental Biology of Fishes 43: 121-134.

Wisenden, B.D., Lanfranconi-Izawa, T.L. and Keenleyside, M.H.A. (1995). Fin digging and leaf lifting by the convict cichlid, Cichlasoma nigrofasciatum: examples of parental food provisioning. Animal Behaviour 49: 623-631.

MANUSCRIPT RECEIVED 9 OCTOBER 2012; ACCEPTED 27 JANUARY 2013. 